This is the peer reviewed version of the following article: Schapper, A, Urban, F. Large dams, norms and Indigenous Peoples. Development Policy Review 2021; 39(Suppl. 1): O61-O80, which has been published in final form a https://doi.org/10.1111/dpr.12467. This article may be used for non-commercial purposes in accordance with Wiley Terms and Conditions for self-archiving.

This article has been accepted for publication and undergone full peer review but has not been through the copyediting, typesetting, pagination and proofreading process, which may lead to differences between this version and the Version of Record. Please cite this article as doi: $\underline{10.1111 / \mathrm{dpr} .12467}$

This article is protected by copyright. All rights reserved 


\section{Large Dams, Norms and Indigenous Peoples}

Andrea Schapper ${ }^{1}$ and Frauke Urban ${ }^{2}$

\section{Abstract}

Motivation: In this paper, we examine the role of norms in protecting the rights of Indigenous Peoples with regard to hydroelectric dams. We argue that the way large-scale dams are built and managed - including their impacts on Indigenous Peoples - varies according to the political context of the host country. In more restrictive political contexts, norms may often be neglected or compromised.

Purpose: The political system and domestic legislation are crucial factors that need to be considered in more depth in research scholarship on dams. We contribute to filling this research gap by presenting a comparative analysis of the Bakun Dam in Malaysia and the Gibe III dam in Ethiopia demonstrating that norms tend to be ignored or compromised in restrictive and authoritarian political environments.

Approach and Methods: We compare the similarities and differences of these two dam projects systematically drawing on empirical field research comprising interviews, focus group discussions and the analysis of primary and secondary documents.

Findings: Our research reveals that international and private norms are often neglected in partly free or unfree political systems. Even domestic legislation can be circumvented by a strong or authoritarian state government, and this can lead to serious delays and neglect of protective standards.

${ }^{1}$ Senior Lecturer in International Politics, University of Stirling, UK. Corresponding author. Email: andrea.schapper@stir.ac.uk

${ }^{2}$ Associate Professor in the Management of Sustainable Energy Systems, KTH Royal Institute of Technology, Stockholm, Sweden

Acknowledgements:

We would like to thank Fadzilah Majid Cooke and Gusni Bin Saat, as well as Giuseppina Siciliano, May TanMullins and Grace Mang for contributing to the fieldwork in Malaysia / China for this paper. We are grateful to the local communities who participated in the interviews and focus group discussions and who shared their experiences with us. We would like to thank all project participants of the "China goes global" project and those who contributed to the research. We are grateful to the UK Economics and Research Council ESRC for funding the research on Malaysia (reference ES/J01320X/1). Also, we are grateful to all the interviewees in Ethiopia, especially the non-governmental organizations (but also representatives from government and international organizations), who agreed to provide information although being exposed to risks and restrictions. Thanks to an anonymous reviewer who helped to improve the paper. Finally, the opinions expressed are those of the authors only and do not necessarily represent the opinions of the Royal Institute of Technology KTH or the University of Stirling. 
Policy Implications: International standards are often more ambitious than national standards and their implementation in the hydropower dams industry can help to improve the social and environmental sustainability of projects. Active civil society organizations can use norms and standards to strengthen social mobilization within the country and can transmit important information outside the country to build transnational alliances. Pressure and persuasion mechanisms can lead to norm change and norm compliance by state actors.

Keywords: Hydroelectric dams, norms, Indigenous Peoples, social inequalities, environment, energy justice

\section{Introduction}

Large hydroelectric dams are often seen as instruments for providing cost-effective, low-carbon energy that can help to reduce energy poverty, increase energy security and mitigate climate change. After decades of decline, due to their severe social and environmental impacts (WCD, 2000), the large dams sector is experiencing a revival today with many hydroelectric dams being built across the world, particularly in low- and middle-income countries. Large hydroelectric dams are being viewed as symbols of development, modernity and progress (Jiahua \& Zhu, 2006) as well as contributing to green growth strategies of many countries worldwide.

Critical scholars highlight that large hydroelectric dams represent a vision of neoliberal, capitalist development at the expense of marginalized communities (Sugden \& Punch, 2014). In this way, dams can reveal ideological challenges to the dominant understanding of development (Gadgil \& Guha, 1994). There is a large number of studies on development-induced displacement and resettlement (e.g. Aiken \& Leigh, 2015; Morvaridi, 2004; Heggelund, 2006) highlighting that already marginalized social groups, such as pastoralists and Indigenous Peoples, are often the most adversely affected. In this paper, we define Indigenous Peoples in accordance with the United Nations (UN) as '[...] inheritors and practitioners of unique cultures and ways of relating to people and the environment [...] who have retained social, cultural, economic and political characteristics that are distinct from those of the dominant societies in which they live' (UNDESA, 2019) and who need to be protected as distinct peoples. Indigenous Peoples usually have their own languages, traditions and culture, which are different from those of the majority population in the country in which they live. Often, Indigenous Peoples have been living on their lands for centuries or more, yet they have rarely had the legal land titles (Aiken \& Leigh, 2011). In the context of large-scale hydroelectric dams, not only are Indigenous Peoples' customary land rights often neglected (Cooke 
et al., 2017) but also communities' abilities to live on their ancestral lands, including the use of water and forests for sustaining livelihoods (Cooke et al, 2015). In the past, land has been taken away by resettlement, denying Indigenous Peoples access to rivers or flooding habitation areas, agricultural land and hunting grounds (Schlosberg \& Carruthers, 2010; Aiken \& Leigh, 2015; Cooke et al., 2017). Governments are blamed for using such strategies as ways of 'nation-building' (Gadgil \& Guha, 1994, p. 110).

Grassroots protest groups, social movements and transnational advocacy networks have attempted to raise local concerns about the environment, human rights and Indigenous Peoples. This has been particularly successful when a transnational alliance of advocacy actors was able to link up with domestic allies in democratic contexts to promote norms (Khagram, 2004). Norms related to largescale dam projects have gained more relevance with the creation of the World Commission on Dams (WCD) in 1997. The Commission has already addressed a considerable number of the problems mentioned above and suggested an integrative normative framework to mitigate these (WCD, 2000). However, not much seems to have changed since the launch of international WCD norms in 2000.

In this paper, we argue that although complex constellations of actors are involved in planning and implementing large-scale hydroelectric dams, governments have a crucial role in determining the normative framework and conditions under which dam projects are realized. Thus, the way big dams are built and operated - including their impacts on Indigenous Peoples - varies considerably according to the political context of the host country. In more restrictive political contexts, norms often tend to be neglected or compromised. The political system is a crucial factor that needs to be considered in more depth in research scholarship on dams. Dam projects often involve diverse actors, including international organizations, banks, financiers and investors, construction companies, consultancies, national governments, civil society organizations (CSOs) and local community groups. Many of these actors emphasize the relevance of different norms including WCD standards, the guidelines by the International Finance Corporation (IFC, 2016) the Environmental and Social Safeguard Policies by the World Bank, the Hydropower Sustainability Assessment Protocol by the International Hydropower Association (HSAP, 2015) and the IHA's Sustainability Guidelines from 2018, as well as the Equator Principles for the financial sector (Nordensvard et al., 2015).

In relation to the protection of Indigenous Peoples, the International Labour Organization's (ILO) Convention on the Rights of Indigenous and Tribal Peoples in Independent Countries, adopted in 1989 , is the only legally binding treaty that states can ratify. It contains provisions on justice and indigenous customary law, the right to participation and to being consulted, as well as rights over lands, traditional territories and natural resources (ILO, 1989; see also Anaya, 2009; Lillich et al., 
2009; Yupsansis, 2010; Philips, 2015). The Universal Declaration on the Rights of Indigenous Peoples adopted by the UN General Assembly in 2007 is customary international law and affirms the right to self-determination, including equality and non-discrimination, rights over lands, territories and natural resources, rights to self-government, autonomy and cultural integrity as well as the right to free, prior and informed consent (UN, 2007; see also Gilbert, 2007; Engle, 2011; Ornelas, 2014).

Usually, however, state actors within a given political system and domestic legal framework decide whether or to what extent norms are considered (Urban et al., 2015). History has shown that in restrictive political systems, environmental and social standards tend to be neglected, whereas they are more likely to be respected in less restrictive political systems.

In this paper, we draw on recent studies highlighting the role of the state in sustainable energy transformation processes (Lederer, Wallbott, \& Bauer, 2018; Yankson, et al., 2018; Moe, 2016) and the meaning of norms and safeguards in hydroelectric dam projects (Kirchherr et al., 2017; Hensengerth, 2015; Hensengerth, 2013). We present a comparative analysis of the Bakun Dam in Malaysia and the Gibe III dam in Ethiopia as two case studies of large-scale hydroelectric dam projects. Our research finds that norms are largely neglected in restrictive and authoritarian political environments. We compare the similarities and differences of these two dams systematically in relation to Indigenous Peoples, drawing on empirical field research. Section 2 explores the methodology and the conceptual framework, sections 3 and 4 present the two case studies, section 5 discusses the findings comparatively and section 6 concludes.

\section{Methods and Conceptual Framework}

\section{Case studies and case selection}

The research involved an interdisciplinary, multi-sited, comparative case-study approach based on in-depth, empirical research. For our fieldwork, we selected the Bakun Dam in Borneo, East Malaysia and the Gibe III dam in the Lower Omo Valley, Ethiopia. These are both large hydropower dams that have been framed as instruments of green development, modernity and progress by the central government and were pursued despite adverse effects on Indigenous Peoples and the environment. The negative social and environmental consequences of both dam projects will be discussed in the case studies in more detail.

The Bakun Dam is the largest dam in Southeast Asia (Choy, 2004) and the second tallest concretefaced rockfill dam in the world. It is located in the tropical rainforest of Sarawak, Borneo, East 
Malaysia, on Indigenous Peoples' land on the Balui River in the Upper Rajang River Basin (Fam, 2017). It has a generating capacity of 2,400 megawatts and an estimated cost of about US\$2.6 billion. It started operating in 2011 (Cooke et al., 2017; Sovacool \& Balun, 2011). A very complex set of actors was involved in the construction process, which was led by the Malaysia-China Hydropower Joint Venture, comprising Sinohydro (China) and SimeDarby (Malaysia).

About 9,100 Indigenous Peoples had to be resettled for the dam construction (Cooke et al., 2017). The Bakun Dam was the first in a series of large dams within the Sarawak Corridor Of Renewable Energy (SCORE), which is aiming to bring 'green development' and low-carbon infrastructure to a part of Malaysia that is left behind from a development perspective (Sovacool \& Bulan, 2013). Malaysia aspires to be a high-income country by 2030 . The government regards large hydropower dams as motors of economic growth, attracting industrial investments, creating employment and enabling Indigenous Peoples to be merged into a modern Malaysian nation-state that is fit for the 21st century.

The Gibe III dam is currently Africa's tallest dam in operation (International Rivers, 2011, p. 2 ) ${ }^{3}$ it is located about 300km southwest of Addis Ababa, at the Omo River. Its construction began in 2006 and it was officially inaugurated in 2016. By producing 1,870 megawatts of electricity, the dam more than doubles Ethiopia's capacity, enabling it to sell energy to neighbouring Djibouti, Kenya and Sudan. Project development and oversight are undertaken by the Ethiopian Electric Power Corporation (EEPC). Salini Impregilo, an Italian construction company, received the Gibe III building contract in 2006. The largest part of the funding comes from the Export-Import Bank of China (ExIm) (International Rivers, 2011). Ethiopia aims to become the African leader in low-carbon growth and to become a middle-income country by 2025 with the help of its Climate Resilient Green Economy (CRGE) strategy (GoE, 2011). Transforming the energy sector by investing into hydropower, including Gibe III, is a crucial part of this strategy. However, the dam also constrains water flow into Lake Turkana in Kenya, leading to substantially reduced water and biodiversity. This has serious impacts on the socio-economic well-being of Indigenous Peoples in Turkana County in Kenya. This transboundary dimension and unique ambitions for green growth make Ethiopia a politically significant case to study (Ragin, 2004, p. 127).

These two country cases were selected because they both represent relatively restrictive political systems, specifically one partly free system (Malaysia) and one authoritarian system (Ethiopia). Both have ambitious green-growth policies aiming at becoming a high-income country and a middleincome country respectively. This paper will analyse how international and private standards are

\footnotetext{
${ }^{3}$ Once the Grand Renaissance dam is in operation, this will be Ethiopia's largest dam.
} 
neglected by the governments in both political contexts - and binding domestic norms are largely compromised. However, there is still an interesting variation between the two cases. In a partly free system, civil society can mobilize for protests leading to increased pressure for implementing at least certain minimum standards, such as compensation, in Malaysia. In the authoritarian system, i.e. Ethiopia, governmental regulations become even more restrictive, culminating in severe constraints on Indigenous Peoples and non-governmental organizations (NGOs) aiming to represent them.

\section{Methods}

For the Bakun Dam, 20 semi-structured in-depths interviews were conducted with local communities directly affected by the dam and seven focus group discussions (FGDs) with the same communities. In addition, eight interviews were conducted with institutional actors, from dam operators, national and local governments to NGOs in Malaysia, as well as 23 interviews with Chinese actors such as dam-builders, regulators and financiers. This makes a total of 51 interviews and seven FGDs with 66 individuals on which we draw for this paper. In-depth discussions were held with relevant Malaysian representatives including Sarawak Hidro, Sime Darby, representatives in the Prime Minister's office and NGOs located mainly in Sarawak. Interviews with Chinese stakeholders included dam-builders like Sinohydro, China Three Georges Corporation, financiers like ExIm Bank, Chinese ministries and regulators. The fieldwork was conducted between 2014 and 2016.

For the Gibe III dam, field research was difficult to conduct due to the political situation in Ethiopia at that time. Construction of the Gibe III dam commenced in 2006 and the large-scale project became part of Ethiopia's CRGE strategy launched in 2011 (GoE, 2011). In between, the government passed the 2009 Charities and Societies Proclamation. This law heavily restricts the activities of NGOs in the country, in particular with respect to human rights. The restrictive political context created an atmosphere of constraints, and it was almost impossible to conduct interviews with representatives from NGOs, and even UN officials are very careful in voicing any concerns. Thus, Ethiopia resembled many features of environmental authoritarianism, emphasizing how governments increase their capability of dealing with complex issues at the environment-development nexus by becoming more rigorous and restrictive (Beeson, 2010; Moore, 2014).

Against this background, field research in Ethiopia was limited and could only be undertaken with care. This empirical study draws on a content analysis of primary documents provided by international NGOs like Human Rights Watch (HRW), International Rivers and Survival International. Moreover, a content analysis of primary government documents was conducted. These contained, 
among others, the Growth and Transformation Plan, the CRGE vision, and the Green Economy Strategy. During a period of field research in September 2013 in Addis Ababa, 12 expert interviews were conducted. Four of the interviewees were representatives from the Ministry of Energy and Water, the Ministry of Environmental Protection and Forestry, and the Ministry of Agriculture. Two experts from the governmental Ethiopian Development Research Institute and one academic expert from a national university - all of whom substantially contributed to designing Ethiopia's CRGE were interviewed. Two interviews were carried out with specialists from the United Nations Development Programme (UNDP) and the United Nations Environment Programme (UNEP). In addition, three interviews were conducted with representatives from NGOs and a FGD with development cooperation experts. Finally, one more interview was conducted outside Ethiopia with an international NGO that had terminated activities in the country after the Charities Proclamation came into force.

We coded and categorized the qualitative data from interviews and FGDs using narrative analysis and content analysis (Wolcott, 1990; Wiles et al., 2005), using Nvivo 10 and MAXQDA software. This enabled us to analyse several cases comparatively, to draw parallels and to identify any differences (Yin, 2009).

\section{Conceptual Framework}

We use theories of political ecology (PE) and insights from norm research in International Relations (IR) as a conceptual framework for this study. Political ecology deals with the human-environment relationship and raises questions about power to examine how political economy drivers and ecological processes are entwined (Wolf, 1972; Greenberg \& Park, 1994; Perreault et al., 2015). We use these ideas to analyse the bargaining among actors involved in dam construction as well as the conflicts caused by different forms of control over access to natural resources, such as land, water, forests and energy (Bryant \& Bailey, 1998; Blaikie, 1985; Peet \& Watts, 2004). Power relations between different actors are at the heart of this framework (Tan-Mullins, 2007). Analysing these allows us to explore the uneven distribution of access to and control of natural resources. Bryant and Bailey (1997) developed three fundamental assumptions regarding the political ecology of lowand middle-income countries. First, there is an unequal distribution of the costs and benefits related to environmental change. Second, this unequal distribution reinforces pre-existing social and economic inequalities. Third, the unequal distribution of the costs and benefits and the reinforcing of pre-existing inequalities have political implications, such as in relation to power dynamics. Power 
relates to the ability to control and/or have access to the financial benefits from natural resource exploitation (Bryant, 1996, 1997; Peluso, 1992; Dauvergne, 1994).

In this paper, we aim to combine PE approaches with norm scholarship from IR. We argue that norms, if properly observed, can reduce inequalities that are at the heart of PE analysis. As inequalities are often exacerbated through hydroelectric dam projects, we argue that common norms can help to protect local population groups that are adversely affected by dams, through social standards, or with regard to ecosystems and biodiversity negatively affected by dams, through environmental standards. In IR, norms are defined as '...] collective expectations about proper behaviour for a given identity' (Jepperson et al., 1996, p. 54). Governments adopt norms for different reasons: to become an accepted member of the international community, to foster cooperation, diplomatic relations and trade or as a reaction to domestic pressures. Risse et al. (1999) have developed the spiral model of human rights change to explain how repressive governments adopt norms as a reaction to pressure exerted by domestic civil society and opposition groups building a strong alliance with transnational advocacy networks. In a review of the spiral model, they suggest that lacking capacities can also hamper norm compliance (Risse et al., 2013; Schapper, 2014; Jenichen \& Schapper, 2017).

Recently, norm research from IR is increasingly used for analysing large-scale dam projects. Hensengerth (2015) uses the literature on norm diffusion and contestation to highlight how global norms are used at a local level to justify different development paths. Kirchherr et al. (2017) distinguish between three sets of norms. These are (1) international norms and safeguards, including WCD, IFC or HSAP guidelines (2) domestic norms and legislation of the host country and (3) private standards introduced by the investor or dam-builder. However, only the norms of the host country, i.e. domestic laws, are legally binding and play a crucial role for dam realization. International standards, such as the guidelines of the WCD, are more likely to be respected in democratic contexts when domestic civil society can link up with transnational advocacy groups to exert pressure on the government with a view to norm enforcement (Khagram, 2004; Risse et al., 1999). Increasingly, safeguards are also introduced by private dam investors. Crucial examples are the principles on foreign investment published by China's State Council or the Export-Import Bank of China Loan Project Environmental and Social Evaluation Guidelines. Kirchherr et al. (2017) and Nordensvard et al. (2015) found that China is increasingly adopting norms in the context of its 'Going Out Policy' and these standards can be even more ambitious than domestic legislation in host countries (p. 530). Table 1 provides an overview of norms for the dams industry. 
In this paper, we argue that the political system and context are crucial factors in understanding whether norms can reduce inequalities caused by dam projects. Therefore, we will compare two case studies on dams, one in a partly free political system (Malaysia) and an authoritarian political system (Ethiopia) to show that international and private norms are neglected and domestic standards are compromised in more restrictive political environments.

Table 1: Overview of norms relevant for the global dams industry

\begin{tabular}{|l|l|l|l|}
\hline Norms & Examples & Legal obligation & $\begin{array}{l}\text { Inequality situation } \\
\text { addressed }\end{array}$ \\
\hline International & $\begin{array}{l}\text { WCD guidelines } \\
\text { IFC guidelines } \\
\text { HSAP guidelines }\end{array}$ & Non-binding & $\begin{array}{l}\text { Environmental } \\
\text { inequalities, } \\
\text { social inequalities, } \\
\text { economic inequalities }\end{array}$ \\
\hline Domestic & $\begin{array}{l}\text { Environmental law } \\
\text { Social standards } \\
\text { Civil society regulations } \\
\text { ElA legislation }\end{array}$ & Binding & \\
\hline Private & $\begin{array}{l}\text { Principles on foreign investment } \\
\text { published by China's State Council, } \\
\text { The Export-Import Bank } \\
\text { of China Loan Project } \\
\text { Environmental and Social } \\
\text { Evaluation Guidance, 2007 }\end{array}$ & Voluntary & $\begin{array}{l}\text { depending on political } \\
\text { context }\end{array}$ \\
\hline
\end{tabular}

\section{Case Study of the Bakun Dam}

\section{Malaysia's Political Context and Normative Framework}

Malaysia is a multi-cultural, multi-lingual and multi-religious federal constitutional monarchy located in Southeast Asia. Its political elite comes mainly from the Malay majority, whereas other major ethnic group are of Chinese and Indian descent.

Malaysia is regarded as "partly free" according to Freedom House Index (FHI). The press is not free in Malaysia, but highly regulated (FHI, 2018). Freedom of assembly, freedom of speech, political freedom and freedom of religion could be considered as being partly restricted. Some civil society organisations have difficulties operating in Malaysia, for example as official registration for certain groups is being denied by the government. Malaysia has a multi-party system, yet the United Malays National Organisation (UMNO) was in charge for over 60 years from 1957 until 2018, until the opposition coalition Pakatan Harapan (PH) gained power. The current Prime Minister Mahathir 
Mohamad, first ruled Malaysia under UMNO between 1981 and 2003, and is currently also the PH's party chairman.

Gordon Means (1996, p. 103) argues that Malaysia, as well as neighbouring Singapore, is a "soft authoritarian" state, that has incorporated democratic institutions from its colonial times, yet democratic ideals and practices have not been retained. Many studies suggest that the Malaysian economy is influenced by political patronage, particularly in the natural resources sector where there are close ties between firms and politics (Sen \& Tyce, 2019; Wahab et al, 2018).

With regard to Indigenous Peoples, the Malaysian government supported the UN Declaration on the Rights of Indigenous Peoples when it was adopted in the UN General Assembly in 2007, but it did not ratify the ILO Indigenous and Tribal Peoples Convention.

East Malaysia on the island of Borneo includes the states of Sarawak and Sabah, which are less populated and less developed than Peninsular Malaysia, but have rich biodiversity with primary rainforest. They have their own administrative system that is separate from the federal government in Malaysia. This has caused tensions over the Bakun Dam, which was primarily viewed as a federal government project based in Sarawak.

Plans for the Bakun Dam were first discussed in the 1960s and were shelved again in 1990 when it became clear that electricity demand was too low in Sarawak to build a large dam. Yet, the dam plans were revived in 1993 by then Prime Minister Mahathir Mohamad, which resulted in parts of the work being carried out, such as logging large parts of the area, resettling the Indigenous Communities, building the river diversions tunnels and auxiliary cofferdams, so that future largescale infrastructure could be built. Several Malaysian firms were involved in a complex consortium, as well as Korean, Brazilian, Australian and European firms. However, the Asian financial crisis led to a stop of the constructions in 1997. Finally, a third attempt of dam-building was made in 2000 when the Malaysia-China Hydro Joint Venture consortium, led by Malaysian Sime Engineering Berhad (part of Sime Darby) and China's Sinohydro Corporation (part of PowerChina), built the Bakun Dam as part of an Engineering Procurement Construction (EPC) / turnkey contract. This means the Malaysia-China Hydro Joint Venture consortium was responsible for the construction of the dam and the safety of workers. Other contractors included Alstom (France) and IMPSA (Argentina) for electrical and mechanical contracting, such as for the turbines, Dong Ah (Korea) for water diversion works and a wide range of other contractors and consultants. Sarawak Hidro, a Malaysian StateOwned Enterprise (SOE) is the operator and owner of the dam (Sovacool \& Bulan, 2011). 
The dam was proposed and developed by the Federal Malaysian Government, which was also in charge of the planning and paying for the costs of resettling the Indigenous Peoples. The actual implementation of resettlement was done by the State Government of Sarawak. There are also rumours that the former Chief Minister of Sarawak, Abdul Taib Mahmud, and his cronies might have profited from the Bakun Dam indirectly, in relation to commercial logging of the area when the tropical forest was cleared for the reservoir. In general Sarawak's economy is said to be closely linked to Mr Mahmud's business elite.

According to Malaysian law, there is a legal obligation to carry out a risk assessment for any development project or public policy that can potentially have adverse effects on the environment. This is embedded in Malaysian law since 1974 as part of the Environmental Quality Act and more specifically in the Environmental Impact Assessment order of 1987. This legislation has been regularly updated, last in 2007 (Department of Environment, 2013). The Environmental and Social Impact Assessment (ESIA) for the Bakun Dam was carried out at least twice, due to the delayed building process. The report was only made public 10 years later. One major problem was limited consultation of Indigenous Peoples (Cooke et al., 2017).

The motivation for building the Bakun Dam is mainly political. Sarawak is very sparsely populated and the electricity demand is low. Electricity transport from East Malaysia to West Malaysia via high voltage under-sea cables have never materialised, aluminium smelters that were supposed to consume parts of the electricity have never been built and the Trans-Borneo Power Grid Interconnection that would supply electricity across the entire island of Borneo, including to Indonesia and Brunei, has never happened either. Yet, the government aims to build a total of 12 large dams in Sarawak for enabling the SCORE. The objective of SCORE is to attract energy-intensive industries to Sarawak whose activities would be powered by the construction of 20,000 megawatts of new hydroelectric capacity along a $320 \mathrm{~km}$ corridor between 2008-2030 (Sovacool \& Bulan, 2013). Some scholars argue that building the Bakun Dam marked the start of the 'hard path' of energy production, where large-scale and technologically complex energy solutions were regarded as better and more modern than small-scale, decentralised and technologically less complex options (Sovacool \& Valentine, 2011). SCORE also serves as a strategy for nation building, by industrializing the areas, creating employment in the industrial sector, aligning development standards, monetizing a previously non-monetarised part of society and attempting to integrate and level the playing field between ethnic minorities and the majority Malays. Large dams are also viewed as instruments of a green growth strategy that can push Malaysia towards becoming a high income country by 2030 . 
The following quote by a representative of a dam-building firm exemplifies this notion of bringing modernism and civilisation to the marginalised:

"The local people were living in the forest before the construction of the hydropower station. The houses they now live in are much better than before. The government also built schools for them, which provides them with more chances to receive education...They are indigenous people. They do not wear too much clothes. The children there are basically barefoot....But there has been a lot of progress, they have basically been civilized." (Interview dam-builder).

As the quote above suggests, Indigenous Peoples in Sarawak are often portrayed as 'primitive' and 'backwards' living in the rainforest far away from 'civilisation' (Aiken \& Leigh, 2015). The displacement and resettlement was therefore an important tool to bring Indigenous Peoples in line with modern Malaysia.

\section{Environmental and Socio-Economic Implications of the Bakun Dam}

The dam development is located in a biodiversity hotspot in the tropical rainforest of Borneo. It includes a reservoir occupying $14,170 \mathrm{~km}^{2}$, the biggest in Malaysia, covering $12 \%$ of Sarawak. An estimated 70,000 ha of old-growth rainforest were deforested for dam construction (Choy, 2005a). The access roads into the rainforest also allowed further industrial development, particularly those of palm oil and logging companies.

The reservoir, the dam sites and the access roads to the dam have destroyed valuable habitat for rare and endangered species. Access to natural resources, such as land, water, forest and food has changed significantly after dam construction. Water quality has decreased, the water available at the resettlement site is polluted, filled with sediment and smelly. Sometimes there is no water provision for several days. The locals reported:

"The water is not clean, it is like mud. ... How are we going to drink and eat? That is why many of us in Asap always fall sick" (quote from FGD, Uma Badeng).

The Bakun Dam project involved the resettlement of about 9,100 Indigenous Orang Ulu Peoples from the ethnic groups Kayan, Kenyah, Lahanan, Ukit and Penan (Cooke et al., 2017) who have reportedly lived on these lands for about 450 years (Choy, 2005b). Before the resettlement, the Indigenous Peoples used to live in longhouses by the river and were practising subsistence farming, horticulture, fishing as well as hunting and gathering in the rainforest (Aiken \& Leigh, 2015; Aiken \& 
Leigh, 2011; Alexander, 2008). Some of them were nomadic, like the Penan (Brosius, 1986, 2000, 2001). Each ethnic group has a rich culture based on their own traditions, language and practices.

The resettlement, the confiscation of customary land, loss of access to the river, forests and fertile land, as well as loss of the traditional way of life are the most wide-ranging socio-economic impacts of the dam. The Indigenous Peoples who used to live by the banks of the Balui River and used this habitat for their subsistence, now live far away from the water and from their traditional hunting, foraging and fishing grounds in purpose-built longhouses in several resettlement sites in Sungai Asap. Each family received a compensation of 3 acres of land and a flat or bilek (a unit of one 'door' in a longhouse).

The villagers stated to have received several types of compensation, including for lost houses, lost farm land and lost crops. However, it took a long time, in some cases even several years, to receive compensation payments. The valuation of the old houses that were later inundated by the water in the reservoir was rather low. Interviewees indicated that the Government set a maximum value of RM 52,000 [USD 12,400] to be paid for compensation for lost houses. If the value of the old house was estimated lower, the villagers had to pay the difference between the value of the old house and the new house. Many Indigenous Peoples were disputing this process and the valuation system. After more than ten years of civil protest and resistance, the government agreed that no money had to be paid back to the state and some villagers managed to get back the difference they had already paid.

Scarcity of land is also an issue, as is the quality and fertility of the new land. There is a change in livelihoods as villagers in the new settlement rely more on the market for the provision of food and other goods that they were able to get freely from the forest and dam area before resettlement. Therefore, life is more costly in the resettlement area and livelihoods have decreased for some villagers who do not have access to remunerative jobs. There is a lack of employment, a lack of land for subsistence farming or commercial agricultural activities and a lack of access to natural resources. Dependence on the market has also led to a monetarisation of life.

Livelihood strategies have dramatically changed from the old to the new settlement area with new jobs, such as cultivation of cash crops like oil palm and pepper, logging, tourism activities, and working at the dam. Younger people welcome this, although many choose to go to Peninsular Malaysia for finding jobs or getting an education. Education has improved; students have easier access to schools which are located closer to the resettlement site. There is easier access to roads and healthcare clinics; electricity access is also provided post-dam construction. However, there is a 
generational divide, with the older generation feeling particularly disillusioned and left-behind. Also, the previously nomadic Penan are worse off than other Indigenous Groups, because their life changes have been particularly abrupt. Many of the Penan are disproportionally impoverished compared to the other ethnic groups.

\section{Case Study of the Gibe III Dam}

Ethiopia's Political Context and Normative Framework

The Federal Democratic Republic of Ethiopia today is known as an authoritarian government which is "not free" according to FHI (FHI, 2019). Since October 2016, the Ethiopian government has declared several states of emergency to regain governmental control over oppositional protest of various ethnic groups as a reaction to rigorous development programmes. Ethiopia's parliament lifted the last state of emergency in June 2018 (BBC, 2018) and many new hopes for democratic reforms are associated with the 2018 appointment of the first Oromo Prime Minister Abiy Ahmed.

The Ethiopian government supported the UN Declaration on the Rights of Indigenous Peoples when it was adopted in the UN General Assembly in 2007, but did not ratify the ILO Indigenous and Tribal Peoples Convention. According to the Ethiopian constitution adopted in 1995 and the 2002 Ethiopian Environmental Impact Assessment Proclamation, there is a legal obligation to carry out a risk assessment for any development project or public policy that can potentially have adverse effects on the environment. There was no adequate compliance with these domestic norms in the case of Gibe III as one downstream assessment was only carried out in 2009, i.e. three years after dam construction had already commenced (EEPCO, 2009). This study also did not evaluate any transboundary effects in Kenya (Avery, 2017). After carrying out their own evaluation studies on the basis of international norms, the World Bank (WB), the European Investment Bank (EIB) and the African Development Bank (AfDB) announced in 2010 that they were no longer considering funding Gibe III due to serious doubts relating to adverse social and environmental impacts (International Rivers, 2011). This withdrawal remained without any effect as the Chinese ExIm bank provided the funding without conducting another independent review of environmental and social consequences (Avery, 2017). ExIm bank's guidelines highlight that the host countries' norms are the standards according to 
which projects are evaluated and that the project owners are obliged to submit an environmental and social impact assessment report (China ExIm Bank, 2008). In the case of Gibe III, the EEPC delivered a deficient report that neglected international standards, domestic legislation and the norms of the private investor.

In 2010, the Ethiopian government adopted its five-year Growth and Transformation Plan (GoE, 2010) and incorporated Gibe III as a green growth project into its Climate Resilient Green Economy Strategy. During the same year, a new civil society law, the Charities and Societies Proclamation, entered into force. This law, which has now been reformed after Abiy Ahmed took over leadership in 2018, heavily restricted and controlled the activities and publications of all third sector groups in the country. During the time Gibe III was established, it prevented critical voices, social mobilization and protest and enabled the government to pursue its restrictive development path. Moreover, it prohibited NGOs to raise awareness regarding international norms and socio-economic inequalities:

"[...] indigenous communities are suffering. And [...] we don't have really the mandate and the power to talk about this and bring this to the table for the government to engage in advocacy and the like. [...], they will say, delete this or your registration will be cancelled." (Interview NGO 1).

With this severely limited representation and advocacy from civil society, the Ethiopian government could bypass international, domestic and private norms leading to exacerbated inequalities in the context of Gibe III implementation.

\section{Environmental and Socio-Economic Implications of Gibe III}

The establishment of the Gibe III dam has severe environmental consequences in the Lower Omo river basin in Ethiopia and Lake Turkana region in Kenya. As the volume of water flow in the river is substantially reduced, termination of flooding eliminates water-loving vegetation around the river. Oxygen and nutrient levels in the river change, leading to a decrease in water quality. Agriculture livelihood of Indigenous Peoples in the Omo delta is being destroyed and fish habitat of the river Omo and Lake Turkana eliminated due to lacking oxygen and nutrients. Major changes in water quantity and quality result in the drying of grazing lands, accelerated desertification processes and decrease in soil quality. The former seriously affects livestock mortality and dependence on cultivation. Riverine forests are destroyed, including woodland-based subsistence food production (Carr, 2017; 2012, pp. 86-90). 
This massive interference with a delicate ecosystem does not only lead to biodiversity loss but also comes with severe socio-economic consequences for Indigenous Peoples due to the massive impact on their livelihood activities (Carr, 2017; 2012, p. 4). About 200,000 residents of the Lower Omo Valley in Ethiopia and another 300,000 people living around Lake Turkana in Kenya are affected by the dam and associated endeavours for irrigated agricultural development. Indigenous communities, like the Mursi and Bodi, living alongside the river Omo have been forcibly evicted from their ancestral lands by the government and military forces. Harassment, violence and arbitrary arrests were used, in particular against those protesting (HRW, 2012). Another related major problem is that land traditionally occupied by indigenous communities is offered to private investors. There are no ownership certificates because it has always become communally inherited. An expert from a domestic NGO summarizes this as a serious problem:

"Did the people agree? - No. Did they give their free and full consent? - No. Did they get, at least an amount of compensation? - No. [...]" (Interview NGO_2).

Resettled communities were either forced to settle in the ecologically degraded upland plains or into the Delta region. The latter is already inhabited by the Dasanech and additional settlers aggravate resource scarcity, particularly with respect to water (Carr 2012, p. 4). According to the government, relocated people should now stay in one place and work on the sugar plantations which were part of the agriculture development plans. They were promised to receive social services through improved infrastructure, including houses, schools and access to hospitals. By the time HRW conducted field research in the area, this infrastructure was not yet in place (HRW, 2012, p. 53). However, food aid delivered by the government was used as an incentive for people to remain in these locations (HRW, 2012, p. 61). Coerced displacement is not only opposed to domestic law, international human rights and indigenous rights (HRW, 2012) but is also forcing Indigenous Peoples to 'modernize' their life styles as they are seen by the government as: "[...] very communal, very primitive" (Interview, Ministry of Water and Energy_1). By engaging into a rights discourse, NGOs are blamed to hamper modernization:

"So if you are talking about [...] the rights of these people, then you will be challenging [...] the modernization of these communities." (Interview NGO_1).

This means that communities that were already susceptible to climate change consequences, such as droughts, shifting seasons and heat stress, were even more disadvantaged as they lost access to their water and lands necessary for maintaining their subsistence (Interview NGO_1). This has led to exacerbated social and economic inequalities in Ethiopia's society. The authoritarian government 
pursued a restrictive development path and circumvented protective norms at all levels that would have enabled indigenous communities to participate in the decisions affecting them.

\section{Comparative Analysis and Discussion}

Although both dam projects have been established in different world regions with varying development challenges, comparing them reveals a considerable number of striking commonalities. Bakun and Gibe III are both part of a whole series of hydropower dam projects in Malaysia and Ethiopia, based on ambitious ideas of using natural resources to massively increase low carbon energy generation and electricity provisions to promote economic growth and to develop to a highincome or a middle-income country respectively. These so-called green development strategies are in both cases government-led with the highest state bureaucrats playing a significant initiating role. In both countries, there is a legal requirement to carry out risk assessments before initiating development projects. However, in both cases, publicly available social and environmental impact assessments were delayed until after dam-building had already started. Thus, the assessments did not fulfil their main function anymore and could not prevent adverse environmental and social consequences. Both dam projects have attracted major investments, such as by the Chinese ExIm Bank. Dam development took place in close cooperation between state-linked agencies and foreign private actors. China's ExIm Bank relies on the legislative framework of the host countries' norms (China ExIm Bank, 2008) and does not usually carry out an independent review of social and environmental impacts.

The following similarities in relation to environmental and socio-economic impacts can be revealed: Bakun and Gibe III entail severe environmental implications mainly relating to land, soil and desertification, forests, water, fish habitat, wildlife and biodiversity. These environmental consequences are impacting vulnerable ecosystems and are closely interlinked with further adverse socio-economic effects on Indigenous Peoples. In both cases, land rights and territorial entitlements of Indigenous Peoples' were infringed upon (Cooke, et al., 2015). Because of their special relationship with their lands, this has severe social consequences for them. Both dam projects are embedded in a government-led discourse on modernization and progress. Indigenous Peoples, who are regarded as "primitive" by the elite, are integrated into a modernized state with enhanced infrastructure, monetarized economy, employment opportunities and improved social services. Relocation of local population groups in both cases was state-led and affected Indigenous Peoples most severely; their customary lands, their cultural practices, traditional livelihoods and subsistence. 
Comparing Bakun and Gibe III, a few differences can be observed. The first relates to the role of international norms. In the case of Gibe III, the World Bank had been involved in the strategic planning process. However, after carrying out impact assessments in 2010, the WB, together with EIB and the ADB, no longer considered funding the dam project. The World Bank claimed that there was a lack of transparency and that Gibe III did not comply with the norms anchored in its Environmental and Social Safeguard Policies (Mamme, 2015). ${ }^{4}$ For the Bakun dam, three attempts were made to build the project with several domestic and foreign contractors; these plans were abandoned twice, partly due to financial reasons. ESIAs were reported to have been carried out in accordance with national and international norms, however it later emerged that there was limited consultation of Indigenous Peoples, the ESIA process was delayed and the report was only made public 10 years later (Cooke et al., 2017).

Another difference relates to the extent of relocations. Whereas about 9,100 Indigenous People from the ethnic minorities Kayan, Kenyah, Lahanan, Ukit and Penan were displaced in Malaysia and resettled due to dam construction, as many as 103,000 from the ethnic groups Mursi, Bodi, Kwegu (Muguji), Karo, Hamer, Suri, Nyangatom and Daasanach had to be resettled in Ethiopia. The Gibe III dam also has serious trans-boundary effects on another 300,000 Indigenous People depending on Lake Turkana in Kenya. There was no prior consultation with Kenyan officials or the Indigenous Peoples affected (Mutambo, 2017). Such cross-border implications cannot be observed in Malaysia.

In the case of Gibe III, attempts of resettlement have led to violence. Arbitrary arrests, forced displacements and in single cases even killings took place when Indigenous Peoples protested against relocations. In Malaysia, protest occurred in a non-violent way; mainly in the form of filing law suits against the government, for example to fight low compensation levels. Table 1 summarizes the comparison.

Finally, there were some positive implications in the Bakun dam case, such as for younger generations who might be able to get a better education and access more formal employment opportunities, as well as for women who have closer access to maternal healthcare. Yet, there is a large disparity between different ethnic groups. In the case of the Gibe III dam there are hardly any positive implications for the affected local people.

Table 2: Comparative analysis of the Bakun and the Gibe III dams

\begin{tabular}{|l|l|l|}
\hline & Bakun & Gibe III \\
\hline
\end{tabular}

${ }^{4}$ Controversially, the WB decided to fund transmission lines between Ethiopia and Kenya later on in 2012,
arguing that the power transported does not come from Gibe III even though critics doubt this. 


\begin{tabular}{|c|c|c|}
\hline \multicolumn{3}{|l|}{ Commonalities } \\
\hline Development vision & \multicolumn{2}{|c|}{$\begin{array}{l}\text { Low carbon development using natural resources / green } \\
\text { development agenda }\end{array}$} \\
\hline Governmental discourse & \multicolumn{2}{|c|}{ Modernization and progress } \\
\hline $\begin{array}{l}\text { Domestic normative } \\
\text { framework }\end{array}$ & \multicolumn{2}{|c|}{$\begin{array}{l}\text { Risk assessments regarding environmental and social impacts } \\
\text { required but neglected/delayed in both cases }\end{array}$} \\
\hline Actor constellation & \multicolumn{2}{|c|}{$\begin{array}{l}\text { Government-led with a consortium of Chinese private } \\
\text { investments and Malaysian/Ethiopian funders }\end{array}$} \\
\hline Socio-economic impacts & \multicolumn{2}{|c|}{$\begin{array}{l}\text { Relocations, disruption of traditional livelihoods \& self- } \\
\text { sufficiency } \rightarrow \text { potential for (improved) access to social services }\end{array}$} \\
\hline Environmental impacts & \multicolumn{2}{|c|}{$\begin{array}{l}\text { Endangered ecosystems, desertification, decreased access to } \\
\text { water, decreased water quality, decreased soil quality, } \\
\text { elimination of vegetation, reduction of fish habitat }\end{array}$} \\
\hline \multicolumn{3}{|l|}{ Differences } \\
\hline International Norms & $\begin{array}{l}\text { Two earlier attempts to build } \\
\text { the dam failed due to } \\
\text { economic reasons. On the } \\
\text { third attempt the dam was } \\
\text { built by a Chinese-Malaysian } \\
\text { consortium. International } \\
\text { norms were attempted, but } \\
\text { compromised }\end{array}$ & $\begin{array}{l}\text { Withdrawal of World Bank, } \\
\text { African Development Bank and } \\
\text { European Investment Bank } \\
\text { due to non-compliance }\end{array}$ \\
\hline Resettlement & Non-violent relocations & Violent relocations \\
\hline Extent of resettlement & 9,100 Indigenous Peoples & 103,000 Indigenous Peoples \\
\hline Trans-boundary effects & No & Yes \\
\hline Governmental restrictions & Implicit & Yes \\
\hline Political system & Partly free & Authoritarian, not free \\
\hline Opposition & $\begin{array}{l}\text { Opposition partly successful as } \\
\text { demands for payments for } \\
\text { new houses dropped by the } \\
\text { Government, more than } 10 \\
\text { years after resettlement }\end{array}$ & Opposition unsuccessful \\
\hline
\end{tabular}

Relating these empirical results back to our analytical framework, we can assert that both, Bakun and Gibe III, contribute to environmental damages and to deepening political and societal inequalities. Those who are often already marginalized within their countries and societies, i.e. Indigenous Peoples, are disproportionately affected. Resettlement can destroy livelihoods and the basis for self-sufficiency, and if carried out in a violent way, it can infringe on human rights. The strong alliance between governments and private investors makes it difficult for civil society actors to represent diverging interests. Private and state-owned building companies and investors are, in 
the end, the main beneficiaries of these neoliberal undertakings, again revealing exacerbated power inequalities between private for-profit actors and affected local communities.

Embedded in a discourse of modernization and progress, governments legitimize their actions by the need for transitions to low-carbon economies and the necessity to substantially increase energy production for development. What we could observe with the help of our case studies is that, even though latest research shows that investors, such as the Chinese ExIm bank, increasingly develop private voluntary norms and standards (Kirchherr et al., 2017), the domestic political context and governmental decisions are crucial when it comes to considering or neglecting these norms. If the government of the host country decides to neglect these and if there is no meaningful and active civil society raising awareness to these standards, they will not be considered and they will not prevent the exacerbation of social inequalities. Similarly, international guidelines and standards, such as those of the WCD and the WB, do not prevent environmental, social and economic inequalities, if governments find a way to circumvent them. Once investors offer large-scale funding, countries do not rely on financial support that is conditional to norm compliance. This could be demonstrated in the case of Ethiopia when Gibe III construction could continue - due to funding offered by ExIm Bank - even though the WB, ADB and EIB did not finance the project anymore. For the Bakun dam, three attempts at building the dam were made, making dam-building only possible once the Malaysia-China Hydro Joint Venture consortium took charge. Domestic norms, that are usually binding, play a crucial role for preventing adverse effects on social groups and the environment. But whether these norms are meaningfully implemented depends on the political context. If there are no checks and balances by civil society and domestic opposition groups (and no information about norm violations can be transferred outside the country), the government might delay adequate environmental and social impact assessments, even though they are mandatory. In such situations, domestic norms cannot prevent economic, social and environmental inequalities and adverse effects on Indigenous Peoples.

Previous research acknowledges that norms play an important role in democratic contexts of dambuilding and in relation to an active civil society that is needed to build a strong transnational alliance against questionable governmental decisions (Khagram, 2004). Successful social mobilization can suspend dam-building (Schapper et al., 2019) or even prevent the construction of a dam with a court decision, as in the case of the São Manoel Dam in Brazil. A court ruling can be used for further effective social activism (International Rivers, 2013). From human rights research we know that norms can unfold even in repressive political contexts, if a domestic opposition can transfer information about norm violations to transnational advocacy networks who then pressure the 
government from above (transnational alliance) and from below (domestic opposition) to change their policies (Risse et al., 1999, 2013). Building on this research we suggest that it is crucial to investigate how norms can protect Indigenous Peoples and prevent exacerbated inequalities in restrictive, authoritarian and less free political systems.

\section{Conclusion and Policy Recommendations}

As we face climatic challenges and a growing demand for affordable low-carbon energy, there is a need for more renewable energy capacity. Against this backdrop, the building of hydroelectric dams is on the rise. Governments fostering dam-building often use these as symbols of modernity, progress and sustainable development, linking their own development objectives with donor funding priorities or foreign investors' interests relating to green energy production. Our comparative analysis of the Bakun dam in Malaysia and the Gibe III dam in Ethiopia reveals some common patterns among large dams from two different regions, suggesting that in the way they are currently implemented, hydroelectric dams can exacerbate economic, social and environmental inequalities at the expense of Indigenous Peoples.

Indigenous Peoples' traditional livelihoods and self-sufficiency are endangered through the disruption of delicate ecosystems and resettlement. In authoritarian countries with rigorous resettlement practices and restrictions on civil society, dam-building can even lead to severe human rights infringements and violence, such as in Ethiopia. This can trigger conflict between the state and society but also create transboundary conflicts as water flow does not stop at national borders. Hence, there is a danger that hydroelectric dam projects may not be sustainable in the long run.

Referring back to Bryant and Bailey's (1997) three fundamental assumptions in analysing the political ecology in low- and middle-income countries, we found the following. First, the costs and benefits associated with building large dams are distributed unequally, with local people in rural areas particularly Indigenous Peoples - being disproportionally affected by large dam construction, while the benefits are predominantly reaped by firms and government elites. Second, this research found that unequal distribution inevitably reinforces existing social and economic inequalities, with the poor and marginalized being further marginalized. Third, the unequal distribution of costs and benefits and the reinforcing of pre-existing inequalities hold political implications in terms of the altered power relationships that result. Issues of dam-building and resettlement have become political issues, with the ultimate aim to bring modernity to so-called 'primitive' communities and to 
eradicate their 'backwards-looking' lifestyles. Against this backdrop, several authors argue that energy planning for large dams needs to follow the principles of energy justice and climate justice (Siciliano et al., 2018; Schapper, 2018).

International, domestic and private norms - if properly observed - can mitigate these adverse effects on already marginalized people and can help to prevent energy injustice. The international norm of free, prior and informed consent (FPIC) as an integral part of the 2007 UN Declaration on Indigenous Peoples' Rights, for instance, can increase participation of Indigenous Peoples in decision-making processes. Although the declaration is non-binding, it is still considered international customary law. Free and informed consent in relation to relocation is also stipulated in the legally binding 1989 ILO Indigenous and Tribal Peoples Convention (neither ratified by Malaysia nor Ethiopia). If appropriately implemented, FPIC can be an important mechanism for protecting Indigenous Peoples' rights, their lands, territories and natural resources. If properly observed, FPIC strengthens Indigenous Peoples' decision-making power as they can withhold consent if they conclude that project implementation will have detrimental effects (Raftopoulos \& Short, 2019). Domestic norms to carry out social and environmental impact assessments can lead to reconsiderations, alterations or changes in decisions to protect Indigenous Peoples. Private standards introduced by investors might also be meaningful as they can lead to better compensation schemes or increased transparency. However, our research has demonstrated that international and private norms are often neglected in partly free or unfree political systems. Even domestic legislation can be circumvented by a strong or authoritarian government, and this can lead to serious delays and neglect of protective standards.

In light of these findings, we conclude with the following policy recommendations. First, the political system was not addressed in the 2000 WCD guidelines. However, we need to know much more about the impact of international, private and domestic norms in the context of dam-building in partly free und unfree political systems. The cases studied in this paper, Malaysia and Ethiopia, have demonstrated how the government may choose to bypass domestic and international standards in order to foster economic development. Thus, we need to conduct more comparative research investigating this relationship. This would be helpful for policy-makers, international and national banks and financiers, and private investors with respect to the risks attached to dam-building and norm compliance in restrictive political contexts. Second, if private standards are raised (Kirchherr et al., 2017) and investors and contractors insist on compliance, governments may find it more difficult to circumvent voluntary protection schemes and international standards. This is also advantageous for private investors and contractors as projects may be less conflict-prone and more sustainable. In 
the cases of Malaysia and Ethiopia, contestation, conflict and protest could have been avoided or minimized had private and voluntary standards, such as consultation and FPIC, been observed. Third, an active civil society can accelerate social mobilization within the country (pressure on the government from below) and can transmit information outside the country to build transnational alliances (pressure on the government from above). Pressure and persuasion mechanisms can lead to norm change and norm compliance by state actors with a view to protecting Indigenous Peoples from exacerbated inequalities. In the cases of Malaysia and Ethiopia this means that an active involvement of civil society representatives and a strengthening of their decision-making powers in the process of dam implementation could have avoided an increase in injustice between those who profit and those who are adversely affected by hydroelectric dams, i.e. Indigenous Peoples.

First submitted August 2018

Final draft accepted June 2019

\section{References}

Aiken, R., \& Leigh, C. (2015). Dams and indigenous peoples in Malaysia: development, displacement and resettlement. Geografiska Annaler, Series B, Human Geography, 97(1), 69-93.

Aiken, R., \& Leigh, C. (2011). In the way of development: indigenous land-rights issues in Malaysia. The Geographical Review, 101(4), 471-497.

Alexander, J. (2008). The Lahanan of the Balui, 1963-2006. Borneo Research Bulletin, 39, 104-127.

Anaya, J. (2009). International human rights and indigenous peoples. New York: Kluwer Publications.

Andre, E. (2012). Beyond hydrology in the sustainability assessment of dams: A planner's perspective - The Sarawak experience. Journal of Hydrology, 412-413, 246-255.

Baird, I., Shoemaker, B., \& Manorom, K. (2015). The people and their river, the World Bank and its dam: revisiting the Xe Bang Fai River in Laos. Development and Change, 46, 1080-1105.

BBC. (2018). Ethiopia declares national state of emergency. Retrieved from: http://www.bbc.co.uk/news/world-africa-43091248 [1 June 2018].

Beeson, M. (2010). The coming of environmental authoritarianism. Environmental Politics, 19, 276294.

Blaikie, P. (1985). The Political Economy of Soil Erosion in Developing Countries. London: Longman. 
Bratman, E. (2015). Passive revolution in the green economy: activism and the Belo Monte Dam. International Environmental Agreements: Politics, Law and Economics, 15, 61-77.

Brosius, P. (1986). The forest and the nation: negotiating citizenship in Sarawak, East Malaysia. In R. Rosaldo (Ed.), Cultural Citizenship in Island Southeast Asia: Nation and Belonging in the Hinterlands (pp. 76-133). Berkeley: University of California Press.

Brosius, P. (2001). Local knowledges, global claims: on the significance of indigenous ecologies in Sarawak, East Malaysia. In J. Grim and L. Sullivan (Eds.), Indigenous traditions and ecology (pp. xxx). Cambridge, MA: Harvard University Press and Center for the Study of World Religions.

Brosius, P. (2000). The Western Penan of Borneo. In R. B. Lee and R. H. Daly (Eds.), The Cambridge encyclopaedia of hunters and gatherers (pp. xxx). Cambridge: Cambridge University Press.

Bryant, R. (1997). Beyond the impasse: the power of political ecology in third world environment research. Area, 29, 5-19.

Bryant, R., \& Bailey, S. (1997). Third world political ecology. London: Routledge.

Carr, C. (2012). Humanitarian Catastrophe and Regional Armed Conflict Brewing in the Transborder Region of Ethiopia, Kenya and South Sudan: The Proposed Gibe III Dam in Ethiopia. Africa Resources Working Group. Berkeley, CA: University of California at Berkeley.

Carr, C. (2017). River basin development and human rights in Eastern Africa - a policy crossroads. Open Access: Springer.

Choy, K. Y. (2004). Sustainable development and the social and cultural impact of a dam-induced development strategy -the Bakun experience. Pacific Affairs, 77(1), 50-68.

Choy, K. Y. (2005a). Energy demand, economic growth, and energy efficiency -the Bakun Daminduced sustainable energy policy revisited. Energy Policy, 33, 679-689.

Choy, K. Y. (2005b). Dam-induced development and environmental and social sustainability: The Bakun industrialization strategy revisited. Journal of Economic Issues, 39(1), 123-150.

Cooke, F., Nordensvard, J., Bin Saat, G., Urban, F., \& Siciliano, G. (2017). The Limits of social protection: the case of hydropower dams and indigenous peoples' land. Asia \& the Pacific Policy Studies, 4, 437-450. 
Cooke, F., Saat, G., Gani, N., \& Urban, F. (2015). The land issue in the water, energy and food security nexus. In A. Hezri (Ed.), Water, energy and food security nexus (pp. 123-131). Singapore: Konrad Adenauer Foundation.

Cooke, F. M., Saat, G. B., Siciliano, G., \& Urban, F. (2017). Chinese dam building, renewable energy and socio-ecological change in East Malaysia. In G. Siciliano and F. Urban (Eds.), Chinese hydropower development in Africa and Asia: Challenges and opportunities for sustainable global dam-building (pp. xxx). London \& New York: Routledge.

Department of Environment. (2013). EIA Procedure and Requirements in Malaysia. Retrieved from: http://www.doe.gov.my/eia/wp-content/uploads/2013/06/EIA-Procedure-andRequirementsin-Malaysia.pdf [31 May 2018].

Dauvergne, P. (1994). The politics of deforestation in Indonesia. Pacific Affairs, 66, 497-518.

Donor Assistance Group. (2014). DAG Informal Field Visit Report: South Omo Zone. Final Report. Addis Ababa.

Endicott, K. (2016). Malaysia's 'Original People': past, present and future of the Orang Asli. Singapore: Singapore National University Press.

Engle, K. (2011). On fragile architecture: The UN Declaration on the Rights of Indigenous Peoples in the context of human rights. European Journal of International Law, 22, 141-163.

Fam, S. D. (2017). China came, China built, China left? The Sarawakian experience with Chinese dam building. Journal of Current Chinese Affairs, 3, 119-158.

Finnemore, M., \& Sikkink, K. (1998). Norm dynamics and political change. International Organization, $52,887-917$.

Freedom House. (2018). Freedom in the World. Retrieved from: https://freedomhouse.org/report/freedom-world/freedom-world-2018 [31 May 2018].

Freedom House. (2019). Freedom in the World. Retrieved from: https://freedomhouse.org/report/freedom-world/freedom-world-2019 [14 August 2019].

Gadgil, M., \& Guha, R. (1994). Ecological conflicts and the environmental movement in India. Development and Change, 25, 101-136. 
Gerring, J. (2007). Case study research: principles and practices. Cambridge: Cambridge University Press.

Gilbert, J. (2007). Indigenous rights in the making: The United Nations Declaration on the Rights of Indigenous Peoples. International Journal on Minority and Group Rights, 14, 207-230.

GoE. (2010). Growth and Transformation Plan. Addis Ababa: Government of Ethiopia.

GoE. (2011). Ethiopia's Climate-Resilient Green Economy: Green Economy Strategy. Addis Ababa: Government of Ethiopia.

Greenberg, J., \& Park, T. (1994). Political ecology. Journal of Political Ecology, 1, 1-12.

Heggelund, G. (2006). Resettlement programmes and environmental capacity in the Three Gorges Dam Project. Development and Change, 37, 179-199.

Hensengerth, O. (2015). Global norms in domestic politics: environmental norm contestation in Cambodia's hydropower sector. The Pacific Review, 28, 505-528.

Hensengerth, O. (2013). Chinese hydropower companies and environmental norms in countries of the global South: The involvement of Sinohydro in Ghana's Bui dam'. Environment, Development and Sustainability, 15, 285-300.

HRW. (2012). What will happen if hunger comes? Abuses against the indigenous peoples of Ethiopia's Lower Omo Valley. New York: Human Rights Watch.

HRW. (2015). There is no time left: climate change, environmental threats, and human rights in Turkana County, Kenya. New York: Human Rights Watch.

ILO. (1989). Convention No. 169 Concerning Indigenous and Tribal Peoples in Independent Countries. Adopted by the International Labour Conference: Geneva.

International Rivers. (2011). Ethiopia's Gibe III Dam: Sowing Hunger and Conflict. Berkeley, CA: International Rivers.

International Rivers. (2012). The New Great Walls: A Guide to China's Overseas Dam Industry. Berkeley, CA: International Rivers.

International Rivers. (2013). Federal Court Suspends Public Hearings for Controversial São Manoel Dam. Retrieved from: https://www.internationalrivers.org/resources/federal-court-suspendspublic-hearings-for-controversial-s\%C3\%A3o-manoel-dam-8096 [16 April 16, 2018]. 
IPCC. (2011). Intergovernmental Panel on Climate Change. Special Report on Renewable Energy Sources and Climate Change Mitigation. Summary for Policy-Makers. Retrieved from: http://www.ipcc-wg3.de/report/IPCC_SRREN_SPM.pdf [13 August 2017].

Jenichen, A., \& Schapper, A. (2017). Between global ambitions and local change: how multi-level cooperation advances norm implementation in weak state contexts. Journal of International Relations and Development, 20, 1-28.

Jepperson, R., Wendt, A., \& Katzenstein, P. (1996). Norms, identity and culture in national security. In P. Katzenstein (Ed.), The culture of national security: norms and identity in world politics (pp. 33-75). New York: Columbia University Press.

Khagram, S. (2004). Dams and development: transnational struggles for water and power. Ithaca, NY: Cornell University Press.

Kirchherr, J., Matthews, N., Charles, K., \& Walton, M. (2017). 'Learning it the Hard Way': Social safeguards norms in Chinese-led dam projects in Myanmar, Laos and Cambodia. Energy Policy, $102,529-539$.

Lederer, M., Wallbott, L., \& Bauer, S. (2018). Tracing sustainability transformations - drivers of Green Economy approaches in the Global South. Journal of Environment and Development, 27, $3-25$.

Lillich, R. B., Hannum, H., Anaya, S. J., \& Shelton, D. (2009). International human rights: documentary supplement. Austin, TX: Wolters Kluwer.

Mamme, S. (2015). The Role of the World Bank in the Dam Projects in Ethiopia: A Case of Inconsistency? Master's Thesis, University of Malta.

Means, G. P. (1996). Soft authoritarianism in Malaysia and Singapore. Journal of Democracy, 7(4), 103-117.

Moore, S. (2014). Modernisation, authoritarianism, and the environment: the politics of China's South-North Water Transfer Project. Environmental Politics, 23, 947-964.

Morvaridi, B. (2004). Resettlement, rights to development and the llisu Dam, Turkey. Development and Change, 35, 719-741. 
Mutambe, A. (2017). Ethiopia Denies Forcing Through Gibe Dams Project. Retrieved from: https://www.nation.co.ke/news/Gibe-Dams-project-on-Kenya-and-Ethiopia/1056-381688210d7oky/index.html [15 April 2018].

Nordensvard, J., \& Urban, F. (2015). Social innovation and Chinese overseas hydropower dams: The nexus of national social policy and Corporate Social Responsibility. Sustainable Development, $23,245-256$.

Ornelas, R. T. (2014). Implementing the policy of the U.N. Declaration on the Rights of Indigenous Peoples. The International Indigenous Policy Journal, 5, 1-20.

Peluso, N. (1992). Rich forest, poor people: resources control and resistance in Java. Berkeley, CA: University of California Press.

Peet, R., \& Watts, M. (2004). Liberating political ecology. In R. Peet and M. Watts (Eds.), Liberation ecologies: environment, development and social movements (pp. 3-47). London: Routledge.

Perreault, T., Bridge, G., \& McCarthy, J. (2015). The Routledge handbook of political ecology. Abingdon: Routledge.

Philips, J. (2015). The rights of indigenous peoples under international law. Global Bioethics, 26, 120127.

Raftopoulos, M., \& Short, D. (2019). Implementing Free Prior and Informed Consent: The United Nations Declaration on the Rights of Indigenous Peoples (2007), the Challenges of REDD+ and the case for the Precautionary Principle. International Journal of Human Rights. https://doi.org/10.1080/13642987.2019.1579990.

Ragin, C. (2004). Turning the tables: how case-oriented research challenges variable-oriented research. In H. Brady and D. Collier (Eds.), Rethinking social inquiry (pp. 123-138). Lanham, MD: Rowman \& Littlefield.

Risse, T., Ropp, S., \& Sikkink, K. (eds.). (1999). The power of human rights: International norms and domestic change. Cambridge: Cambridge University Press.

Risse, T., Ropp, S., \& Sikkink, K. (eds.). (2013). The persistent power of human rights: From commitment to compliance. Cambridge: Cambridge University Press.

Schapper, A. (2014). From the global to the local: How international rights reach Bangladesh's children. London: Routledge. 
Schapper, A. (2018). Climate justice and human rights. International Relations, 32(3), 275-295.

Schapper, A., Unrau, C., \& Killoh, S. (2019). Social mobilization against large hydroelectric dams: a comparison of Ethiopia, Brazil and Panama. Sustainable Development (accepted and forthcoming).

Schlosberg, D., \& Carruthers, D. (2010). Indigenous struggles, environmental justice, and community capabilities. Global Environmental Politics, 10, 12-35.

Sen, K., \& Tyce, M. (2019). The elusive quest for high income status - Malaysia and Thailand in the post-crisis years. Structural Change and Economic Dynamics, 48(3), 117-135.

Siciliano, G., Urban, F., Tan-Mullins, M., \& Mohan, G. (2018). Large dams, energy justice and the divergence between international, national and local developmental needs and priorities in the global South. Energy Research \& Social Science, https://doi.org/10.1016/j.erss.2018.03.029.

Sovacool, B., \& Bulan, L. C. (2011). Behind am ambitious megaproject in Asia: the history and implications of the Bakun hydroelectric dam in Borneo. Energy Policy, 39, 4842-4859.

Sovacool, B., \& Valentine, S. (2011). Bending bamboo: restructuring rural electrification in Sarawak, Malaysia. Energy for Sustainable Development, 15, 240-253.

Sovacool, B., \& Bulan, L. C. (2013). They'll be damned: the sustainability implications of the Sarawak Corridor of Renewable Energy (SCORE) in Malaysia. Sustainability Science, 8, 121-133.

Sugden, F., \& Punch, S. (2014). Capitalist expansion and the decline of common property ecosystems in China, Vietnam and India. Development and Change, 45, 656-684.

Tan, Y., Hugo, G., \& Potter, L. (2005). Rural women, displacement and the Three Gorges Project. Development and Change, 36, 711-734.

Tan-Mullins, M. (2007). The state and its agencies in coastal resources management: the political ecology of fisheries management in Pattani, Southern Thailand. Singapore Journal of Tropical Geography, 28, 348-361.

Tilt, B., Braun, Y., \& He, D. (2009). Social impacts of large dam projects: a comparison of international case studies and implications for best practice. Journal of Environmental Management, 90, S249-S257.

UNDESA (2019). Indigenous Peoples at the UN. Retrieved from: https://www.un.org/development/desa/indigenouspeoples/about-us.html [2 May 2019]. 
UN (2007). United Nations Declaration on the Rights of Indigenous Peoples. Adopted by the UN General Assembly: New York.

Urban, F., Nordensvard, J., Siciliano, G., \& Li, B. (2015). Chinese overseas hydropower dams and social sustainability: The Bui Dam in Ghana and the Kamchay Dam in Cambodia. Asia \& the Pacific Policy Studies, 2, 573-589.

Wahab, E. A. A., How, J., Park, J., \& Verhoeven, P. (2018). Political patronage and analysts' forecast precision. Journal of Contemporary Accounting \& Economics, 14(3), 307-320.

WCD. (2000). Dams and Development. A New Framework for Decision-Making: The Report of the World Commission on Dams. London: Earthscan.

Wolf, E. (1972). Ownership and political ecology. Anthropological Quarterly, 45, 201-205.

Yankson, P., Asiedu, A., Owuso, K., Urban, F., \& Siciliano, G. (2018). The livelihood challenges of resettled communities of the Bui dam project in Ghana and the role of Chinese dam-builders. Development Policy Review, 36, 0476-0494.

Yin, R. (2009). Case Study Research: Design and Methods. Thousand Oaks, CA: Sage.

Yupsanis, A. (2010). ILO Convention No. 169 Concerning Indigenous and Tribal Peoples in Independent Countries 1989-2009: An Overview. Nordic Journal of International Law, 79, 433456. 